\title{
RESPON TANAMAN SAWI HIJAU(Brassica juncea L.) TERHADAP PEMBERIAN PUPUK ORGANIK DAN ANORGANIK DI KELURAHAN RURUKAN KECAMATAN TOMOHON TIMUR
}

\section{THE RESPONSE OF GREEN MUSTARD (Brassica juncea L.) GREENS TO THE PROVISION OF ORGANIC AND INORGANIC FERTILIZERS IN URBAN SUBDISTRICT RURUKAN TOMOHON EAST}

\author{
Jeanete A. B. Ngantung1), Jenny J. Rondonuwu2) dan Rafli I. Kawulusan²) \\ 1) Mahasiswa Fakultas Pertanian Unsrat Manado, 95115 \\ 2) Dosen Jurusan Tanah, Fakultas Pertanian Unsrat Manado, 95115 \\ Email : jeanete.ngantung@yahoo.com
}

\begin{abstract}
This study aims to determine the effect of which combination of fertilizer doses is best for the growth of Mustard Plant (Brassica juncea L.).And the research was conducted in Kelurahan Rurukan Tomohon Timur Subdistrict Tomohon City. Soil analysis was conducted in Soil Chemistry and Soil Fertility Department of Soil Agricultural Faculty of Sam Ratulangi University of Manado.This study used a Completely Randomized Design (RAL) consisting of 7 treatment combinations and repeated as many as 4 (four) times to obtain 28 pot experiments. Each pot of the experiment contains $5 \mathrm{~kg}$ of soil. The results showed that soil mixture with various combinations of fertilizers had a significant effect on the height of the green mustard plant, the number of leaves of green mustard greens, and the fresh weight of the green mustard plant.The best combination of soil mixture with Urea, Sp36, and Compost fertilizer is $0.5 \mathrm{gram} /$ pot Urea, $0.375 \mathrm{gram} /$ pot Sp36, and $50 \mathrm{gram} /$ pot compost.
\end{abstract}

Keywords: urea fertilizer, Sp36 fertilizer, compost fertilizer

\begin{abstract}
ABSTRAK
Penelitian ini bertujuan untuk mengetahui pengaruh kombinasi dosis pupuk mana yang terbaik untuk pertumbuhan Tanaman Sawi Hijau (Brassica juncea L.). Dan penelitian dilaksanakan di Kelurahan Rurukan Kecamatan Tomohon Timur Kota Tomohon. Analisis tanah dilakukan di Laboratorium Kimia dan Kesuburan Tanah Jurusan Tanah Fakultas Pertanian Universitas Sam Ratulangi Manado. Penelitian ini menggunakan Rancangan Acak Lengkap (RAL) yang terdiri dari 7 perlakuan kombinasi dan diulang sebanyak 4 (empat) kali sehingga diperoleh 28 pot percobaan. Setiap pot percobaan berisikan tanah seberat $5 \mathrm{~kg}$. Hasil penelitian menunjukkan bahwa berbagai kombinasi pupuk memberikan pengaruh yang nyata terhadap tinggi tanaman sawi hijau, jumlah daun tanaman sawi hijau, dan berat segar tanaman sawi hijau. Kombinasi terbaik dengan pupuk Urea, Sp36, dan Kompos adalah 0,5 gram/pot Urea, 0,375 gram/pot Sp36, dan 50 gram/pot kompos.

Kata kunci : pupuk urea, pupuk SP-36, pupuk kompos
\end{abstract}

Eugenia Volume 24 No. 1 Pebruari 2018 


\section{PENDAHULUAN}

Pupuk merupakan salah satu sumber nutrisi utama yang diberikan pada tumbuhan. Dalam proses pertumbuhan, perkembangan dan proses reproduksi setiap hari tumbuhan membutuhkan nutrisi berupa mineral dan air. Nutrisi yang dibutuhkan tumbuhan diserap melalui akar, batang dan daun. Nutrisi tersebut memiliki berbagai fungsi saling mendukung satu sama lainnya dan menjadi salah satu komponen penting untuk meningkatkan produktivitas pertanian (Dwi, 2007).

Pupuk organik adalah pupuk yang sebagian besar atau seluruhnya terdiri dari bahan organik yang berasal dari tanaman dan atau hewan yang melalui proses rekayasa, dapat berbentuk padat atau cair yang digunakan mensuplai bahan organik untuk memperbaiki sifat fisik, kimia, dan biologi Tanah. Sumber bahan organik dapat berupa kompos, pupuk hijau, pupuk kandang, sisa panen (jerami, tongkol jagung, dan sabut kelapa) dan limbah ternak. Pupuk organik bermanfaat bagi peningkatan produksi pertanian baik kualitas maupun kuantitas, mengurangi pencemaran lingkungan, dan meningkatkan kualitas lahan secara berkelanjutan. Penggunaan pupuk organik dalam jangka panjang dapat meningkatkan produktivitas lahan dan dapat mencegah degradasi lahan. Namun permasalahan umum yang dihadapi pupuk organik adalah rendahnya kadar unsur hara, kelarutan rendah, waktu relatif lebih lama menghasilkan nutrisi yang tersedia yang siap diserap tanaman, dan respon tanaman terhadap pemberian pupuk organik tidak sebaik pemberian pupuk anorganik. Sehingga pupuk organik tidak banyak digunakan, karena dianggap tidak dapat memenuhi kebutuhan nutrisi tanaman (Mardiansyah, 2010).

Pupuk anorganik telah menjadi tradisi pada sistem pertanian yang ada pada saat ini. Hal ini mulai dilakukan sejak revolusi hijau mulai digemakan ke seluruh dunia pada awal dekade 1960an. Pada mulanya, penggunaan pupuk anorganik memberikan dampak positif bagi petani dengan meningkatnya hasil produksi tanaman. Namun penggunaan pupuk ini dalam jangka panjang dapat mengakibatkan tanah mengeras, kurang mampu menyimpan air, dan menurunkan $\mathrm{pH}$ tanah yang pada akhirnya akan menurunkan hasil produksi tanaman (Parman, 2007). Untuk meningkatkan kembali produksi tanaman, petani mulai menambah dosis pupuk sehingga biaya produksi semakin meningkat dan keuntungan petani semakin merosot. Kelangkaan pupuk anorganik yang sering terjadi pada setiap musim tanam menyebabkan banyak petani harus mencari ke daerah lain dan berani membeli mahal demi kelanjutan produksi tanamannya.

Sawi hijau (Brassica juncea L) merupakan salah satu komoditas tanaman hortikultura dari jenis sayuran yang dimanfaatkan daunnya yang masih muda, sebagai makanan sayuran dan memiliki macam-macam manfaat serta kegunaan. Dalam kehidupan masyarakat sehari-hari sawi hijau selain dimanfaatkan sebagai bahan makanan, sayuran juga dapat dimanfaatkan untuk pengobatan (Cahyono, 2003). Sayuran sawi/caisin banyak disukai karena rasanya yang enak dan banyak mengandung: protein, lemak, karbohidrat, $\mathrm{Ca}, \mathrm{P}, \mathrm{Fe}$, Vitamin A,Vitamin B, dan Vitamin C. Selain itu tanaman tersebut juga dapat menghilangkan rasa gatal di tenggorokan pada penderita batuk, sebagai obat sakit kepala dan dapat berfungsi sebagai pembersih darah (Haryanto, $d k k$., 2002) dan tanaman sawi hijau juga sangat membutuhkan pupuk N, $\mathrm{P}, \mathrm{K}$.

Sawi hijau bukan tanaman asli Indonesia, menurut asalnya di Asia. Karena Indonesia mempunyai kecocokan terhadap iklim, cuaca dan tanahnya sehingga dikembangkan di Indonesia. Tanaman sawi dapat tumbuh baik di tempat yang berhawa panas maupun berhawa dingin, sehingga dapat diusahakan dari dataran rendah maupun dataran tinggi. Meskipun demikian pada kenyataannya hasil yang diperoleh lebih baik di dataran tinggi, daerah penanaman yang cocok adalah mulai dari ketinggian 5 meter sampai dengan 1.200 meter di atas permukaan laut. Namun biasanya dibudidayakan pada daerah yang mempunyai ketinggian 100 meter sampai 500 meter dpl. Tanaman sawi tahan terhadap air hujan sehingga dapat ditanam sepanjang tahun. Pada musim kemarau, yang perlu diperhatikan adalah penyiraman secara teratur karena tanaman ini membutuhkan hawa yang sejuk. Tanaman ini cocok bila di tanam pada akhir 
musim penghujan. Tanah yang cocok untuk ditanami sawi adalah tanah gembur, banyak mengandung humus, subur, serta pembuangan airnya baik, derajat kemasaman $(\mathrm{pH})$ tanah yang optimum untuk pertumbuhannya adalah antara $\mathrm{pH} 6$ sampai $\mathrm{pH} 7$.

Kota Tomohon terletak di ketinggian kira-kira 900-1100 meter dari permukaan laut (dpl), diapit oleh 2 gunung berapi aktif, yaitu Gunung Lokon $(1.689 \mathrm{~m})$ dan Gunung Mahawu $(1.311 \mathrm{~m})$. Suhu di Kota Tomohon pada waktu siang mampu mencapai 30 derajat Celsius dan 18-22 derajat Celsius pada malam hari. Berdasarkan data yang didapat dari badan pusat statistik, Kota Tomohon memiliki luas $147,21 \mathrm{~km} 2$ dan terletak pada $01^{\circ} 18^{\prime}$ '51" Lintang Utara dan $124^{\circ} 49^{\prime}$ 40" Bujur Timur. Rurukan merupakan tempat bercocok tanam untuk tanaman hortikultura. Tanaman hortikultura sangat berperan penting sebagai sumber vitamin dan mineral, sawi hijau merupakan salah satu tanaman hortikultura yang digemari oleh masyarakat, sehingga permintaan pasar lebih banyak untuk kebutuhan rumah tangga dan pengadaan bagi restauran-restauran yang menyajikan makanan berbahan dasar sayur. Sebagian besar masyarakat Kelurahan Rurukan berprofesi sebagai petani, tetapi masih kurang petani yang menanam tanaman sawi karena hasil produksi yang tidak maksimal.

Penelitian ini bertujuan untuk: 1) mengetahui respon pemberian pupuk anorganik dan organik terhadap tanaman sawi hijau dan 2) mengetahui kombinasi dosis pupuk anorganik dan organik terbaik terhadap tanaman sawi hijau di Kelurahan Rurukan.

\section{METODE PENELITIAN}

Penelitian ini dilaksanakan di Kelurahan Rurukan Kecamatan Tomohon Timur. Penelitian dilaksanakan mulai bulan Oktober sampai dengan bulan November 2017. Analisis tanah awal dilaksanakan di Laboratorium Kimia dan Kesuburan Tanah Jurusan Tanah Fakultas Pertanian Unsrat Manado.

Bahan-bahan yang digunakan adalah tanah dari kelurahan Rurukan Kecamatan Tomohan Timur, benih sawi hijau, pupuk Urea, pupuk SP-36, pupuk $\mathrm{KCl}$, pupuk kompos, air dan bahan-bahan kimia untuk analisis sifat kimia tanah awal. Sedangkam peralatan yang digunakan dalam penelitian ini adalah sekop, ember, karung, penggaris, gunting, alat tulis menulis, timbangan, polibag, dan kamera sebagai alat dokumentasi.

Penelitian dilakukan dengan menggunakan metode Rancangan Acak Lengkap (RAL) yang terdiri dari 7 perlakuan dan diulang 4 kali, dalam setiap pot berisi $5 \mathrm{~kg}$ tanah. Perlakuan dalam penelitian ini dapat dilihat pada Tabel 1.

\section{Prosedur Penelitian}

Pengambilan tanah yang digunakan dalam penelitian berasal dari kelurahan Rurukan, Kecamatan Tomohon Timur, Kotamadya Tomohon.

Tanah yang sudah diambil, dikering anginkan terlebih dahulu dan diayak dengan ayakan $2 \mathrm{~mm}$ dan selanjutnya dilakukan analisis contoh tanah untuk mengetahui ciri-ciri kimia tanah awal yang meliputi $\mathrm{pH}, \mathrm{N}$-total, P-Bray 1, Ktersedia, dan C-organik.

Tanah yang sudah dikering anginkan kemudian ditimbang seberat $5 \mathrm{~kg} /$ polybag kemudian tanah dicampurkan dengan kompos dan di inkubasi selama 1 minngu.

Selanjutnya tanah tersebut dicampurkan dengan pupuk Urea, SP-36 dan $\mathrm{KCl}$ berdasarkan perlakuan.

Penanaman dilakukan dengan menggunakan benih tanaman sawi hijau dengan cara menabur benih di atas pot kemudian di tutup sedikit dengan tanah di atasnya.

Penjarangan tanaman dilakukan pada umur 7 hari setelah tanam dengan menyisakan satu tanaman yang baik.

Pengamatan pertumbuhan tanaman dilakukan setiap 7 hari sekali selama 6 minggu penanaman dengan mengukur tinggi tanaman dan jumlah daun.

Panen dilakukan pada umur 6 minggu setelah tanam dengan mencabut.

\section{Variabel Pengamatan}

Variabel yang diamati, meliputi tinggi tanaman sawi, jumlah daun tanaman sawi, dan berat segar tanaman sawi. 


\section{Analisis Data}

Data dianalisis dengan menggunakan analsis sidik ragam dan jika ada pengaruh nyata dilanjutkan dengan uji BNT 5\%.

\section{HASIL DAN PEMBAHASAN}

\section{Hasil Analisis Sifat Kimia Tanah Awal dan Pupuk Kompos}

Kandungan hara $\mathrm{C}$-organik dan $\mathrm{P}$ tergolong pada kriteria sedang, $\mathrm{N}$ rendah, $\mathrm{pH}$ tanah netral, dan $\mathrm{K}$ sangat rendah (Tabel 2). Kandungan hara yang demikian tidak memungkinkan tanaman dapat tumbuh optimal. Keadaan ini perlu adanya tindakan perbaikan sifat kimia tanah dengan penambahan bahan organik yang dapat menyediakan unsur yang dibutuhkan tanaman serta memperbaiki sifat fisik dan biologi tanah. Sifat kimia pupuk kompos disajikan pada Tabel 3 .

Tabel 3 menunjukkan kandungan kimia pupuk kompos dimana kandungan $\mathrm{N}, \mathrm{P}, \mathrm{K}, \mathrm{C}$ organik, $\mathrm{C} / \mathrm{N}$, dan $\mathrm{pH}$ menunjukkan hasil sesuai.

\section{Tinggi Tanaman Sawi Hijau}

Berdasarkan pengamatan rataan tinggi tanaman pada tabel 4 menunjukkan hasil yang tertinggi yaitu $24,00 \mathrm{~cm}$ terlihat pada perlakuan 6 dengan pemberian pupuk kombinasi urea +SP-36 + kompos. Perlakuan pemberian pupuk kombinasi pada tanah yang ditanami sawi memberikan hasil yang baik dibandingkan perlakuan pupuk dengan kombinasi yang lain, ini terlihat pada pengamatan tanaman. Hal ini dapat dimengerti karena dalam pertumbuhan tanaman hijau, sangat dibutuhkan $\mathrm{N}$ yang menghasilkan khlorofil serta pembelahan sel dalam pertumbuhan tanaman, $P$ sangat dibutuhkan sumber energi sebagai pembentukan ATP dan ADP dalam tanaman yang reaksi-reaksi metabolisme tanaman, sedangkan kompos sebagai sumbersumber hara yang melengkapi kebutuhan tanaman. Hasil yang terendah terdapat pada perlakuan kontrol yaitu 4,85 .

Tabel 1. Perlakuan Pemberian Pupuk Organik dan Anorganik Terhadap Pertumbuhan Tanaman Sawi Hijau (Table 1. Treatment Of Organic And Inorganic Fertilizers For The Growth Of Mustard Greens)

\begin{tabular}{ccccc}
\hline Perlakuan & $\begin{array}{c}\text { Urea 200 kg/ha } \\
\text { (gram/pot) }\end{array}$ & $\begin{array}{c}\text { SP-36 } \\
150 \mathrm{~kg} / \mathrm{ha} \\
\text { (gram/pot) }\end{array}$ & $\begin{array}{c}\mathrm{KCl} \\
100 \mathrm{~kg} / \mathrm{ha} \\
(\mathrm{gram} / \text { pot })\end{array}$ & $\begin{array}{c}\text { Kompos } \\
20 \text { ton/ha (gram/pot) }\end{array}$ \\
\hline P0 (Kontrol) & - & - & - & - \\
P1 & - & - & - & 50 \\
P2 & 0,5 & 0,375 & 0,25 & - \\
P3 & 0,5 & 0,375 & 0,25 & 50 \\
P4 & - & 0,375 & 0,25 & 50 \\
P5 & 0,5 & - & 0,25 & 50 \\
P6 & 0,5 & 0,375 & - & 50 \\
\hline
\end{tabular}

Tabel 2. Kandungan Hara Tanah Awal

(Table 2. Initial Soil Nutrient Content)

\begin{tabular}{lccc}
\multicolumn{1}{c}{ Jenis Analisis } & Hasil Analisis & Metode Analisis & Keterangan \\
\hline $\mathrm{pH} \mathrm{H}_{2} \mathrm{O}$ & 6.75 & $\mathrm{pH} \mathrm{Meter}$ & Netral \\
$\mathrm{C} \mathrm{Org}(\%)$ & 2.38 & Walkey and Black & Sedang \\
$\mathrm{N}$ total $(\%)$ & 0.19 & Kjeldahl & Rendah \\
$\mathrm{P}$ tersedia $(\mathrm{ppm})$ & 15.36 & Bray 1 & Sedang \\
$\mathrm{K}$ tersedia $(\mathrm{me} \mathrm{K} / 100 \mathrm{~g})$ & 0.08 & Bray 1 & Sangat Rendah \\
\hline
\end{tabular}


Tabel 3. Sifat Kimia Pupuk Kompos

(Table 3. Chemical Properties Of Compost Fertilizer)

\begin{tabular}{lcccccc}
\hline Jenis Pupuk Kompos & $\mathrm{N}(\%)$ & $\mathrm{P}_{2} \mathrm{O}_{5}(\%)$ & $\mathrm{K}_{2} \mathrm{O}(\%)$ & $\mathrm{C}$ Organik (\%) & $\mathrm{C} / \mathrm{N}$ & $\mathrm{pH}$ \\
\hline Tumbuh-tumbuhan & 0.89 & 0.28 & 0.30 & 13.47 & 15.3 & 7.8 \\
\hline
\end{tabular}

Tabel 4. Pemberian Pupuk Organik dan Anorganik Terhadap Rataan Tinggi (cm) Tanaman Sawi Hijau (Table 4. Giving Organic And Inorganic Fertilizers To The Height Of Height (cm) Of Mustard Green Plants)

\begin{tabular}{lc}
\hline \multicolumn{1}{c}{ Perlakuan } & Rataan \\
\hline P0 (Kontrol) & $4,85 \mathrm{a}$ \\
P1 (Kompos) & $20,98 \mathrm{~d}$ \\
P2 (Urea + SP-36 + KCl) & $11,58 \mathrm{~b}$ \\
P3 (Urea + SP-36 + KCl + Kompos) & $20,28 \mathrm{~d}$ \\
P4 (SP-36 + KCl + Kompos) & $17,18 \mathrm{c}$ \\
P5 (Urea + KCl + Kompos) & $19,53 \mathrm{~d}$ \\
P6 (Urea + SP-36 + Kompos) & $24,00 \mathrm{e}$ \\
\hline BNT 5 \% & 1,78
\end{tabular}

Ket : angka-angka yang diikuti huruf yang sama tidak berbeda nyata pada taraf $5 \%$.

Hasil penelitian ini menunjukkan bahwa pemberian pupuk urea + SP-36 + kompos adalah kombinasi pupuk yang paling baik untuk pertumbuhan tinggi tanaman sawi hijau. Hal ini menunjukkan bahwa dosis pupuk Urea $0,5 \mathrm{gram} /$ pot mampu menyuplai nitrogen sesuai jumlah yang dibutuhkan untuk pertumbuhan dan perkembangan pada tanaman sawi hijau karena nitrogen yang terkandung pada pupuk urea merupakan unsur hara yang paling penting, kebutuhan nitrogen sangat baik untuk pertumbuhan tinggi tanaman. Hal ini sejalan dengan pendapat (Erawan, $d k k$., 2013) unsur $N$ berfungsi dalam pertumbuhan vegetatif tanaman, nitrogen merupakan unsur hara esensial untuk pembelahan dan perpanjangan sel sehingga $\mathrm{N}$ merupakan penyusun protoplasma yang banyak terdapat dalam jaringan seperti titik tumbuh. Pemberian dosis pupuk SP-36 0,375 gram/ pot memberikan pengaruh terhadap pertumbuhan tinggi tanaman sawi hijau, serta terjadi interaksi antara tanaman dengan pemberian dosis pupuk SP-36. Hal ini seperti yang dikemukakan oleh Hardjowigeno (1992) bahwa fosfor berfungsi dalam pembelahan sel, memperkuat batang, dan perkembangan akar. Hal ini sesuai dengan pendapat Suwarsono, (1980) yang menyatakan bahwa setiap perlakuan pupuk akan memberikan dampak pertumbuhan yang berbeda, karena tumbuhan akan memberikan tanggapan dengan bermacam-macam cara terhadap perubahan disekelilingnya yang mempengaruhi pertumbuhan tersebut. Dari hasil penelitian ini juga terlihat bahwa pemberian pupuk $\mathrm{K}$ tidak memberikan reaksi yang cukup baik karena unsur $\mathrm{K}$ sudah cukup di dalam tanah, terlihat dari analisa tanah, berarti tanpa adanya tambahan $\mathrm{K}$ sudah dapat dipenuhi dari media tanah yang ada.

Hasil uji BNT menunjukkan adanya perbedaan nyata pada P0 terhadap P1, P2, P3, P4, P5 dan P6, sedangkan P1, P3 dan P5 ditunjukkan oleh notasi yang sama. Tanaman yang diberi perlakuan pupuk organik tanpa pupuk anorganik hasilnya tidak lebih baik bila dibandingkan dengan tanaman yang diberi pupuk anorganik atau kombinasi pupuk organik dan anorganik. Hal ini sesuai dengan pendapat Marsono dan Lingga (2003), pupuk organik mempunyai unsur hara makro dan mikro yang rendah dan tidak dapat langsung diserap tanaman sehingga kebutuhan tanaman akan unsur hara masih belum terpenuhi akibatnya pertumbuhan tanaman pun jadi terhambat akan tetapi pada pupuk anorganik meskipun unsur hara yang terkandung hanya unsur hara makro, tetapi takaran haranya cocok dengan kebutuhan tanaman sehingga kebutuhan tanaman akan unsur hara dapat terpenuhi apalagi bila dikombinasikan antara pupuk organik dan pupuk anorganik maka kebutuhan tanaman akan unsur hara makro maupun 
mikro dapat terpenuhi dan pertumbuhan tanaman pun menjadi lebih baik.

\section{Jumlah Daun Tanaman Sawi Hijau}

Rataan hasil perhitungan jumlah daun pada tanaman sawi hijau setelah diberi perlakuan pupuk organik dan anorganik dapat dilihat pada tabel 5 .

Berdasarkan tabel 5 , menunjukkan hasil daun terbanyak yaitu 9 daun terlihat pada perlakuan 6 dengan pemberian pupuk kombinasi urea + SP-36 + kompos dan pada perlakuan 3 dengan pemberian pupuk urea $+\mathrm{SP}-36+\mathrm{KCl}+$ kompos . Sedangkan yang terendah terdapat pada perlakuan kontrol yaitu 5 daun. Hasil penelitian ini menunjukkan bahwa pemberian pupuk urea + Sp-36 dan kompos dan pupuk urea $+\mathrm{SP}-36+\mathrm{KCl}+$ kompos adalah kombinasi pupuk yang paling baik untuk memperbanyak jumlah daun tanaman sawi hijau dibandingkan dengan dosis yang lainnya. Tanaman mampu menyuplai unsur nitrogen sesuai jumlah yang dibutuhkan untuk proses pertumbuhan dan perkembangan pada tanaman sawi hijau, disebabkan unsur hara nitrogen sangat berperan dalam pertumbuhan vegetatif tanaman misalnya tinggi tanaman dan jumlah daun tanaman sawi hijau. Hal ini sejalan dengan pendapat Novizan (2002) bahwa unsur hara yang dikandung dalam pupuk urea sangat besar kegunaannya bagi tanaman untuk pertumbuhan dan perkembangan. Salah satu fungsi penting nitrogen selama fase vegetatif adalah membantu dalam pembentukan fotosintesis yang selanjutnya digunakan untuk membentuk sel-sel baru, perpanjangan sel dan penebalan jaringan.

Hasil uji BNT menunjukkan adanya perbedaan nyata pada P0 terhadap P1, P2, P3, P4, $\mathrm{P} 5$ dan P6, sedangkan P1, P4 dan P5 di tunjukkan oleh notasi yang sama. Begitu juga P3 terhadap P6 menunjukkan respon yang sama terlihat dari uji BNT. Tanaman sawi pada perlakuan kontrol memiliki jumlah daun yang paling sedikit dengan daun berwarna kuning dan tampak kurus serta kerdil. Hal ini disebabkan tidak tersedianya pupuk nitrogen dalam perlakuan, ini sesuai dengan pendapat Soepardi (1983) yang menyatakan bahwa pupuk nitrogen berperan penting terhadap pembentukan klorofil. Kekurangan pupuk nitrogen akan menyebabkan daun menjadi kuning dan mati. Selain itu dengan tersedianya unsur nitrogen yang banyak, maka klorofil yang terbentuk akan semakin tinggi dimana klorofil berfungsi penting dalam proses fotosintesis. Bagi tanaman sawi hijau unsur nitrogen sangat penting karena sawi hijau merupakan sayuran daun yang dipanen sebelum fase generatif, sehingga pertumbuhan daun yang banyak dan berwarna hijau akan memberikan hasil yang lebih baik. Anonim (2006), adanya unsur nitrogen yang cukup akan menambah pertumbuhan daun dan jumlah unsur nitrogen yang tinggi mempercepat pengubahan karbohidrat menjadi protein yang kemudian diubah menjadi protoplasma.

Tabel 5. Pemberian Pupuk Organik dan Anorganik Terhadap Rataan Jumlah Daun Tanaman Sawi Hijau (Table 5. Giving Organic And Inorganic Fertilizers To The Average Number Mustard Plants)

\begin{tabular}{lc}
\hline \multicolumn{1}{c}{ Perlakuan } & Rataan \\
\hline P0 (Kontrol) & $5 \mathrm{a}$ \\
P1 (Kompos) & $8 \mathrm{c}$ \\
P2 (Urea + SP-36 + KCl) & $7 \mathrm{~b}$ \\
P3 (Urea + SP-36 + KCl + Kompos) & $9 \mathrm{~d}$ \\
P4 (SP-36 + KCl + Kompos) & $8 \mathrm{c}$ \\
P5 (Urea + KCl + Kompos) & $8 \mathrm{c}$ \\
P6 (Urea + SP-36 + Kompos) & $9 \mathrm{~d}$ \\
\hline BNT 5\% & 0,40 \\
\hline Ket : angka-angka yang diikuti huruf yang sama tidak berbeda nyata pada taraf 5\% &
\end{tabular}




\section{Berat Segar Tanaman Sawi Hijau}

Berdasarkan pengamatan rataan berat segar tanaman sawi hijau pada tabel 6 menunjukkan hasil berat segar yang terberat yaitu 67,50 gram terlihat pada perlakuan 6 dengan pemberian pupuk kombinasi urea + SP-36 + kompos yang ditanami sawi memberi hasil yang baik dibanding perlakuan pupuk dengan kombinasi yang lain, ini terlihat pada pengamatan tanaman. Hal ini dapat dimengerti bahwa dalam pertumbuhan tanaman hijau, sangat dibutuhkan $\mathrm{N}$ yang menghasilkan khlorofil serta pembelahan sel dalam pertumbuhan tanaman, $\mathrm{P}$ sangat dibutuhkan sumber energi sebagai pembentukan ATP dan ADP dalam tanaman yang reaksi-reaksi metabolisme tanaman, kompos sebagai sumber-sumber hara yang melengkapi kebutuhan tanaman. Hasil yang terendah terdapat pada perlakuan kontrol yaitu 17,50 gram.

Hasil penelitian ini menunjukkan bahwa pemberian pupuk urea + SP-36 + kompos memberikan hasil rata-rata bobot segar tertinggi dibanding dengan kombinasi pupuk yang lainnya. Hal ini sejalan dengan pendapat Lahadassy (2007), untuk mencapai bobot segar tanaman yang optimal, tanaman masih membutuhkan banyak energi maupun unsur hara agar peningkatan jumlah maupun ukuran sel dapat mencapai optimal serta memungkinkan adanya peningkatan kandungan air tanaman yang optimal pula, sebagian besar bobot segar tanaman disebabkan oleh kandungan air. Adanya unsur nitrogen akan meningkatkan pertumbuhan bagian vegetatif seperti daun. Hal ini sesuai pendapat Marsono dan Lingga (2007), bahwa peranan utama nitrogen bagi tanaman adalah untuk merangsang pertumbuhan secara keseluruhan khususnya batang, cabang, dan daun. Pemupukan akan sangat berpengaruh pada berat tanaman, laju tumbuh tanaman yang meningkat diakibatkan oleh kombinasi pupuk urea, pupuk SP36 dan pupuk kompos dengan dosis yang efektif akan mampu memenuhi kebutuhan nutrisi tanaman sehingga metabolisme tanaman dapat berlangsung dengan baik. Laju pertumbuhan tanaman cenderung meningkat jika unsur hara yang dibutuhkan tanaman cukup tersedia dan dapat segera dimanfaatkan tanaman, seperti halnya nitrogen. Hal ini sejalan dengan pendapat Harlina (2003) yang menyatakan bahwa apabila unsur $\mathrm{N}$ tersedia dalam jumlah banyak maka lebih banyak pula protein yang terbentuk sehingga pertumbuhan tanaman dapat lebih baik.

Hasil uji BNT menunjukkan adanya perbedaan nyata pada P0 terhadap P1, P3, P5, dan P6 sedangkan P0, P2 dan P4 ditunjukkan oleh notasi yang sama, sejalan dengan yang dinyatakan Nyakpa (1988) pemberian dosis pupuk organik dikombinasikan dengan pupuk $\mathrm{N}$ akan lebih efektif hasilnya apabila diberikan dalam dosis tinggi, dan menurut Hardjowigeno (2003) jumlah pupuk yang diberikan berhubungan dengan kebutuhan tanaman akan unsur hara, kandungan unsur hara yang terkandung dalam tanah serta kadar unsur hara yang terkandung dalam pupuk sehingga apabila semua itu terpenuhi maka tanaman pun akan tumbuh baik dan memberikan hasil yang baik pula.

Tabel 6. Rata-rata Berat Segar Tanaman pada Saat Panen (gram)

(Table 6. Average Fresh Weight Of Plants At Harvest (grams))

\begin{tabular}{lc}
\hline \multicolumn{1}{c}{ Perlakuan } & Rataan \\
\hline P0 (Kontrol) & $17,50 \mathrm{a}$ \\
P1 (Kompos) & $40,00 \mathrm{~b}$ \\
P2 (Urea + SP-36 + KCl) & $32,50 \mathrm{a}$ \\
P3 (Urea + SP-36 + KCl + Kompos) & $65,00 \mathrm{~d}$ \\
P4 (SP-36 + KCl + Kompos) & $32,50 \mathrm{a}$ \\
P5 (Urea + KCl + Kompos) & $54,00 \mathrm{c}$ \\
P6 (Urea + SP-36 + Kompos) & $67,50 \mathrm{dc}$ \\
\hline BNT 5\% & 9,40
\end{tabular}

Ket : angka-angka yang diikuti huruf yang sama tidak berbeda nyata pada taraf $5 \%$ 


\section{KESIMPULAN DAN SARAN}

\section{Kesimpulan}

Respon tanaman sawi hijau dengan adanya pemberian pupuk anorganik yaitu kombinasi pupuk urea, pupuk SP-36, pupuk $\mathrm{KCl}$, dan pupuk organik yaitu pupuk kompos memberikan pengaruh nyata pada tinggi tanaman, jumlah daun dan berat segar.

Kombinasi pemberian pupuk anorganik dan organik yang memberikan respon terbaik yaitu pada perlakuan pupuk urea $0,5 \mathrm{gram} /$ pot, SP-36 0,375 gram/pot, dan kompos 50 gram/pot menghasilkan tinggi tanaman sawi hijau $24,00 \mathrm{~cm}$, jumlah daun tanaman sawi hijau 9 helai, dan berat segar tanaman sawi hijau 67,50 gram.

\section{Saran}

Perlu dilakukan penelitian lanjutan pemberian kombinasi pupuk anorganik dan organik dengan dosis yang lebih tinggi di lapangan.

\section{DAFTAR PUSTAKA}

Anonim. 2006. Penyerapan N bagi Tanaman Sawi.

Cahyono, 2003. Budidaya dan Analisis Tani. Kanisius. Jakarta.

Dwi. 2007. Pembuatan Bionutrien Dari Ekstrak Tanaman KPD dan Aplikasinya pada Tanaman Caisin. Skripsi. FPMIPA UPI Bandung. Tidak dipublikasikan.

Erawan. D., W.O. Yani dan A. Bahrun 2013. Pertumbuhan dan Hasil Tanaman Sawi (Brassica juncea L.) pada Berbagai Dosis Pupuk Urea. Jurnal Agroteknos 3:19-25.

Harlina, N. 2003. Pemanfaatan Pupuk Majemuk. Fakultas Pertanian Institut Pertanian Bogor.

Hardjowigeno, S. 1992. IImu Tanah. Mediyatama Sarana Perkasa. Jakarta
Hardjowigeno, S. 2003. IImu Tanah Ultisol. Edisi Baru. Akademika Pressindo. Jakarta.

Haryanto, T. Suhartini dan E. Rahayu. 2002. Tanaman Sawi dan Selada. Depok. Penebar Swadaya.

Lahadassy, J. 2007. Pengaruh Dosis Pupuk Organik Padat Daun Gamal Terhadap Tanaman Sawi. Jurnal Agrisistem 3 (6):5155.

Mardiansyah. 2010. Kajian tentang Potensi Bionutrien MHR yang diaplikasikan pada tanaman sawi (Brassica juncea L.). Skripsi. FPMIPA UPI. Bandung. Tidak dipublikasikan.

Marsono dan P. Lingga. 2007. Petunjuk Penggunaan Pupuk. Penebar Swadaya, Jakarta.

Marsono dan P. Lingga. 2005. Petunjuk Penggunaan Pupuk. Penebar Swadaya, Jakarta.

Novizan. 2002. Petunjuk Pemupukan yang Efektif. Jakarta Agromedia Pustaka.

Nyakpa. 1988. Kesuburan Tanah. Universitas Lampung. Bandar Lampung.

Parman. 2007. Pengaruh Pertumbuhan Pupuk Organik Cair Terhadap Pertumbuhan Tanaman. Laboratorium Biologi Struktur dan Fungsi Tumbuhan Jurusan Biologi Fakultas MIPA UNDIP. Semarang.

Soepardi, G. 1983. Sifat dan Ciri Tanah. Fakultas Pertanian Institut Pertanian Bogor.

Suwarsono. 1980. Kesuburan Tanah. Departemen IImu Tanah. IPB. Bogor. 
